\title{
ANALISA STRATEGI PENGEMBANGAN E-TOURISM SEBAGAI PROMOSI PARIWISATA DI PULAU LOMBOK
}

\author{
Pahrul Irfan ${ }^{1}$ dan Apriani ${ }^{2}$ \\ 1pahrul123@gmail.com, ${ }^{2}$ apriani@stmikbumigora.ac.id \\ ${ }^{12}$ STMIK Bumigora Mataram
}

\begin{abstract}
Abstrak
Sektor pariwisata merupakan salah satu sektor yang memiliki potensi yang besar untuk meningkatkan pendapatan negara dan daerah. Untuk itu diperlukan upaya dalam pengembangan pariwisata di Indonesia. Salah satu program dari pemerintah untuk meningkatkan jumlah wisatawan adalah dengan memprioritaskan pembangunan pariwisata di 10 lokasi yang salah satunya adalah Pariwisata Pulau Lombok. Selain dengan pembangunan daerah pariwisata, hal lain yang dapat dilakukan untuk menaikkan jumlah wisata adalah dengan pemanfaatan teknologi informasi sebagai media promosi melalui e-tourism. Tujuan dari penelitian ini adalah untuk melihat dan menganalisa perkembangan e-tourism yang ada di Pulau Lombok sebagai salah satu cara mempromosikan pariwisata di Pulau Lombok. Teknik analisis yang digunakan pada penelitian ini adalah teknik analisis SWOT dengan melihat faktor internal (kekuatan dan kelemahan) dan faktor eksternal (peluang dan ancaman) yang berkaitan pada perngembangan e-tourism di Pulau Lombok. Hasil dari penelitian ini dapat digunakan oleh pemerintah ataupun pihak terkait dalam menentukan arah pengembangan pariwisata di Pulau Lombok.
\end{abstract}

Kata kunci: analisa SWOT, pengembangan E-Tourism,Pulau Lombok

\section{Pendahuluan}

Penggunaan teknologi informasi adalah beraneka ragam. Setiap pulau yang ada di Indonesia memiliki potensi pariwisata yang menjadi destinasi wisatawan lokal maupun mancanegara. Keindahan objek wisata di Indonesia telah mendapatkan pengakuan dunia internasional, seperti di lansir dari media travel internasional asal Inggris, Rough Guide menempatkan Indonesia pada posisi ke-6 sebagai salah satu dari 20 negara terindah di dunia [1]. Salah satu pulau di Indonesia yang memiliki keindahan pesona alamnya adalah Pulau Lombok yang berada di Provinsi Nusa Tenggara Barat. Keindahan Pariwisata di Pulau Lombok telah mendapatkan pengakuan mancanegara dengan memperoleh penghargaan seperti pada tahun 2015 dan pada tahun 2016 Pulau Lombok meraih penghargaan World's Best Halal Honeymoon Destination dan World's Best Halal Tourism Destination dalam ajang The World Halal Travel Summit \& Exhibition [2].

Pulau Lombok menjadi salah satu destinasi wisata karena keindahan alam serta banyaknya objek wisata yang ada di Pulau Lombok seperti wisata alam, wisata pantai, wisata budaya, dan wisata kuliner. Salah satu destinasi wisata yang disukai wisatawan adalah objek wisata pantai, beberapa pantai di Pulau Lombok yang cukup terkenal antara lain Pantai Senggigi, Pantai Kuta Lombok, dan Pantai Pink. Selain pantai, wisata alam seperti Gunung Rinjani yang merupakan gunung tertinggi ke-3 di Indonesia juga merupakan salah satu destinasi wisatawan. Beberapa objek wisata yang ada di Pulau Lombok antara lain Gili Trawangan, Gili Meno, Gili Air, Gili Kendis, Gili Nanggu, Gunung Rinjani, Air Terjun Benang Kelambu, Air Terjun Tiu Kelep,dan lain-lain.

Berdasarkan data dari Badan Pusat Statistik Provinsi Nusa Tenggara Barat, jumlah kunjungan wisatawan ke Provinsi Nusa Tenggara Barat mengalami peningkatan yang signifikan pada tahun 2012 yaitu 1.629.122 wisatawan [3]. Pada tahun 2015, jumlah kunjungan wisatawan ke Provinsi Nusa Tenggara Barat sebanyak 2.210.527 wisatawan yang terdiri dari 1.061.292 wisatawan mancanegara dan sebanyak 1.149.235 wisatawan nusantara [3]. Peningkatan jumlah wisatawan di Provinsi Nusa Tenggara Barat dan Pulau Lombok khususnya mengalami peningkatan sejak promosi yang dilakukan oleh pemerintah melalui program Visit Lombok Sumbawa (VLS 2012).

Peran dari pemerintah pusat dan pemerintah daerah dalam pengembangan pariwisata di Pulau Lombok dapat dilihat dari rencana strategis di bidang pariwisata yang digadangkan oleh pemerntah dengan menjadikan Kawasan Wisata Mandalika yang berada di Pulau Lombok menjadi salah satu dari 10 destinasi prioritas Indonesia. Sesuai dengan Undang-Undang No. 22 Tahun 1999 Tentang Otonomi Daerah maka pemerintah daerah memiliki peluang dan kesempatan untuk mengelola dan mengembangkan potensi yang ada di wilayahnya dan membangun berbagai sektor kepariwisataan. Pengembangan pariwisata dapat dilakukan dengan cara pengembangan objek pariwisata, pengadaan sarana dan prasarana untuk mendukung pariwisata, dan pemasaran atau 
promosi pariwisata. Pemasaran atau promosi pariwisata pada suatu daerah tergantung dari pengetahuan dan minat wisatwan terhadap suatu objek wisata. Promosi pariwisata dengan menggunakan metode konvensional seperti penyebaran brosur/pamflet, dan sebagainya membutuhkan biaya yang besar dan tidak efektif dilakukan saat ini, sehingga dipandang perlu suatu metode promosi yang lebih efektif yaitu salah satunya melalui promosi internet atau lebih dikenal dengan e-tourism. Di era digital ini, promosi pariwisata melalui internet merupakan cara yang paling efektif dalam mempromosikan pariwasata mengingat kemudahan akses dan jaringan informasi dari internet yang sangat luas memungkinkan promosi pariwisata dapat diakses kapan, dimana, dan siapa saja. Promosi pariwisata melalui internet dapat dilakukan dengan membuat website pariwisata (etourism), promosi video pariwisata melalui youtube dan jejaring sosial, dan ulasana-ulasan yang membahas pariwisata di Pulau Lombok. Pada tahun 2016, website pariwisata http://www.wonderfullomboksumbawa.com/ meraih penghargaan World's Best Halal Tourism Website pada ajang World Halal Tourism Award 2016 di Abu Dhabi [4]. Berdasarkan uraian di atas, maka dipandang perlu membahas pengembangan e-tourism sebagai sarana promosi pariwisata di Pulau Lombok.

Penelitian ini membahas mengenai analisis penerapan e-tourism di Pulau Lombok dengan melihat hubungan dari faktor kekuatan, faktor kelemahan, faktor peluang, dan faktor ancaman dengan menggunakan analisis SWOT. Dari analisis SWOT dapat diketahui faktor internal dan eksternal apa saja yang mempengaruhi pengembangan e-tourism di pulau Lombok sehingga dapat digunakan untuk menentukan strategi dan arah kebijakan pengembangan e-tourism di Pulau Lombok. Peneltian ini merupakan penelitian yang dibiayai oleh Direktorat Riset dan Pengabdian Kepada Masyarakat (DPRM) Kementerian Ristek Dikti sehingga dalam kesempatan ini peneliti mengucapkan terima kasih sebesar-besarnya kepada Direktorat Riset dan Pengabdian Kepada Masyarakat (DPRM) Kementerian Ristek Dikti atas pendanaan penelitian ini dan pelaksanaan Penelitian Dosen Pemula dengan tahun anggaran 2017.

\section{Metode}

Metode penelitian yang digunakan dalam penelitian ini adalah metode penelitian kualitatif dengan melihat perkembngan website pariwisata (e-tourism) dan melihat lebih mendalam kebijakan pemerintah terkait dengan pengembangan pariwisata di Pulau Lombok. Metode yang digunakan untuk pengumpulan data adalah observasi dan dokumentasi. Pengumpulan data melalui observasi dilakukan dengan cara mengamati keadaan di lapangan. Dalam penelitian ini dilakukan pengamatan terhadap kebijakan, strategi, dan keputusan pemerintah dalam pengembangan pariwisata berbasis internet (e-tourism) di Pulau Lombok. Selain itu, observasi juga dilakukan dengan melakukan pengamatan terhadap website pariwisata pulau Lombok, review atau ulasan di internet tentang pariwisata di Pulau Lombok, dan jejaring sosial. Pencarian pariwisata di internet dilakukan dengan menggunakan mesin pencarian Google.

Untuk teknik analisis yang digunakan dalam melakukan analisa pengembangan e-tourism di Pulau Lombok adalah menggunakan teknik analisis SWOT dengan menganalisis kekuatan, kelemahan, peluang dan ancaman. Hasil dari analisis SWOT ini dapat digunakan oleh pemerintah dalam menentukan arah kebijakan dan strategi dalam pengembangan pariwisata di Pulau Lombok.

\section{Hasil dan Pembahasan}

Untuk mendapatkan strategi yang dapat digunakan dalam pengembangan e-tourism di Pulau Lombok dilakukan dengan analisis SWOT dengan melihat aspek internal dan eksternal. Aspek tersebut adalah aspek kekuatan dan kelemahan (faktor internal) dan aspek peluang dan ancaman (faktor eksternal). Keempat aspek tersebut dipaparkan dalam bentuk Internal Strategic Factors Analysis Summary (IFAS) dan External Strategic Factors Analysis Summary (EFAS) yang dapat dilihat pada Tabel 1 dan Tabel 2.

Tabel 1.Strategi Faktor Internal

\begin{tabular}{|c|l|l|c|c|c|}
\hline \multicolumn{2}{|c|}{ No Strategi Faktor Internal } & \multicolumn{3}{c|}{ NIlai } \\
\cline { 3 - 5 } & & Skor & Bobot & Total \\
\hline 1. & & Kekuatan & & & \\
\hline & a. & Penghargaan atas website visitlomboksumbawa & 0.06 & 1 & 0.06 \\
\hline & b. & Jumlah pengguna internet & 0.07 & 2 & 0.14 \\
\hline & c. & Infrastruktur internet di Lombok & 0.07 & 2 & 0.14 \\
\hline & d. & Visi misi terkait e-tourism & 0.1 & 4 & 0.4 \\
\hline & e. & Kebijakan pemerintah terkait e-tourism & 0.1 & 4 & 0.4 \\
\hline
\end{tabular}


ILKOM Jurnal Ilmiah Volume 9 Nomor 3 Desember 2017

\begin{tabular}{|c|c|c|c|c|c|}
\hline & f. & $\begin{array}{l}\text { Kemudahan pencarian di internet dengan kata } \\
\text { kunci pariwisata Lombok }\end{array}$ & 0.1 & 4 & 0.4 \\
\hline & g. & $\begin{array}{l}\text { Program kerja Badan Promosi Pariwisata Daerah } \\
\text { (BPPD) Prov. NTB terkait e-tourism }\end{array}$ & 0.1 & 4 & 0.4 \\
\hline & h. & Media promosi jejaring social & 0.1 & 3 & 0.3 \\
\hline & i. & Populasi broadbrand internet & 0.06 & 2 & 0.12 \\
\hline & j. & Populasi pengguna HP & 0.08 & 2 & 0.16 \\
\hline & k. & Kemudahan reservasi online & 0.06 & 2 & 0.12 \\
\hline & I. & Kemudahan penggunaan website & 0.1 & 3 & 0.3 \\
\hline & & Total & 1 & & 2.94 \\
\hline 2. & & Kelemahan & & & \\
\hline & a. & Jumlah website e-tourism & 0.1 & 4 & 0.4 \\
\hline & b. & Himbauan pembuatan website e-tourism & 0.09 & 4 & 0.36 \\
\hline & c. & $\begin{array}{l}\text { Sumber Daya Manusia mahir di bidang jaringan } \\
\text { dan internet }\end{array}$ & 0.06 & 1 & 0.06 \\
\hline & d. & Ekosistem belum terintegrasi & 0.07 & 2 & 0.14 \\
\hline & e. & Belum ada monitoring dan control system & 0.07 & 2 & 0.14 \\
\hline & f. & Belum ada data management & 0.07 & 2 & 0.14 \\
\hline & g. & Konten e-tourism & 0.1 & 4 & 0.04 \\
\hline & h. & Informasi fasilitas publik pada e-tourism & 0.08 & 3 & 0.24 \\
\hline & i. & Respon feedback (chat room, FAQ) & 0.08 & 3 & 0.24 \\
\hline & j. & $\begin{array}{l}\begin{array}{l}\text { Kinerja Pemerintah sebagai penyaji e-tourism } \\
\text { (sumber daya) }\end{array} \\
\end{array}$ & 0.1 & 4 & 0.4 \\
\hline & k. & Optimasi mesin pencarian (search engine) & 0.1 & 3 & 0.3 \\
\hline & I. & $\begin{array}{l}\text { Belum tersedianya data kepariwisataan Lombok } \\
\text { secara lengkap dan up to date }\end{array}$ & 0.08 & 3 & 0.24 \\
\hline & & Total & 1 & & 3.06 \\
\hline
\end{tabular}

Tabel 2.Strategi Faktor Eksternal

\begin{tabular}{|c|c|c|c|c|c|}
\hline \multirow{2}{*}{\multicolumn{2}{|c|}{ No }} & \multirow[t]{2}{*}{ Strategi Faktor Eksternal } & \multicolumn{3}{|c|}{ Nilai } \\
\hline & & & \multirow[t]{2}{*}{ Skor } & \multirow[t]{2}{*}{ Bobot } & \multirow[t]{2}{*}{ Total } \\
\hline 1. & & Peluang & & & \\
\hline & a. & $\begin{array}{l}\text { Website agen perjalanan yang mempromosikan } \\
\text { pariwisata }\end{array}$ & 0.1 & 4 & 0.4 \\
\hline & b. & Pemasangan CCTV di destinasi wisata & 0.07 & 1 & 0.07 \\
\hline & c. & Kemitraan pemasaran pariwisata & 0.09 & 4 & 0.36 \\
\hline & d. & Jumlah review pariwisata Lombok di internet & 0.2 & 4 & 0.8 \\
\hline & e. & $\begin{array}{l}\text { Digital Marketing melalui partnership (contoh ITX } \\
\text { dan Lombok Travel Mart) }\end{array}$ & 0.09 & 3 & 0.27 \\
\hline & f. & $\begin{array}{l}\text { Platform reservasi dan pemasaran kamar seperti } \\
\text { airyrooms, AirBnB, Red Doorz, } \\
\text { Zen Room, Nida Room }\end{array}$ & 0.07 & 2 & 0.14 \\
\hline & g. & Promosi pariwisata melalui sinema digital & 0.09 & 3 & 0.27 \\
\hline & $\mathrm{h}$. & Indonesia peringkat ke- 6 negara terindah dunia & 0.09 & 2 & 0.18 \\
\hline & i. & Anggaran promosi pariwisata & 0.2 & 4 & 0.8 \\
\hline & & Total & 1 & & 3.29 \\
\hline 2. & & Ancaman & & & \\
\hline & a. & Promosi e-tourism daerah lain & 0.1 & 1 & 0.1 \\
\hline & b. & Display grafis pemasaran e-tourism daerah lain & 0.08 & 3 & 0.24 \\
\hline & c. & Rangking traffic pariwisata di internet & 0.1 & 1 & 0.1 \\
\hline & d. & Fitur pembayaran online & 0.09 & 3 & 0.27 \\
\hline & e. & Fasilitas e-commerce (transaksi lain) & 0.09 & 4 & 0.36 \\
\hline & f. & Persaingan pariwisata dunia & 0.1 & 1 & 0.1 \\
\hline & g. & $\begin{array}{l}\text { Update informasi (pengelolaan website) yang } \\
\text { kurang }\end{array}$ & 0.1 & 2 & 0.2 \\
\hline & h. & $\begin{array}{lllll}\text { Masalah sosial } & \text { budaya } & \text { terkait } & \text { dengan } \\
\text { kecanggungan dan } & \text { kurangnya } & \text { interaksi } & \text { dengan } \\
\end{array}$ & 0.07 & 4 & 0.28 \\
\hline
\end{tabular}


ILKOM Jurnal Ilmiah Volume 9 Nomor 3 Desember 2017

\begin{tabular}{|c|c|c|c|c|}
\hline & manusia & & & \\
\hline i. & $\begin{array}{l}\text { Keamanan transaksi online (sistem pembayaran di } \\
\text { awal ) }\end{array}$ & 0.1 & 2 & 0.2 \\
\hline j. & Kecenderungan global kepariwisataan dunia & 0.09 & 2 & 0.18 \\
\hline $\mathrm{k}$. & $\begin{array}{l}\text { Pemberlakukan ASEAN Free Trade Area (AFTA) } \\
\text { dan ASEAN Framework Agreement on Services }\end{array}$ & 0.08 & 2 & 0.16 \\
\hline & Total & 1 & & 2.19 \\
\hline
\end{tabular}

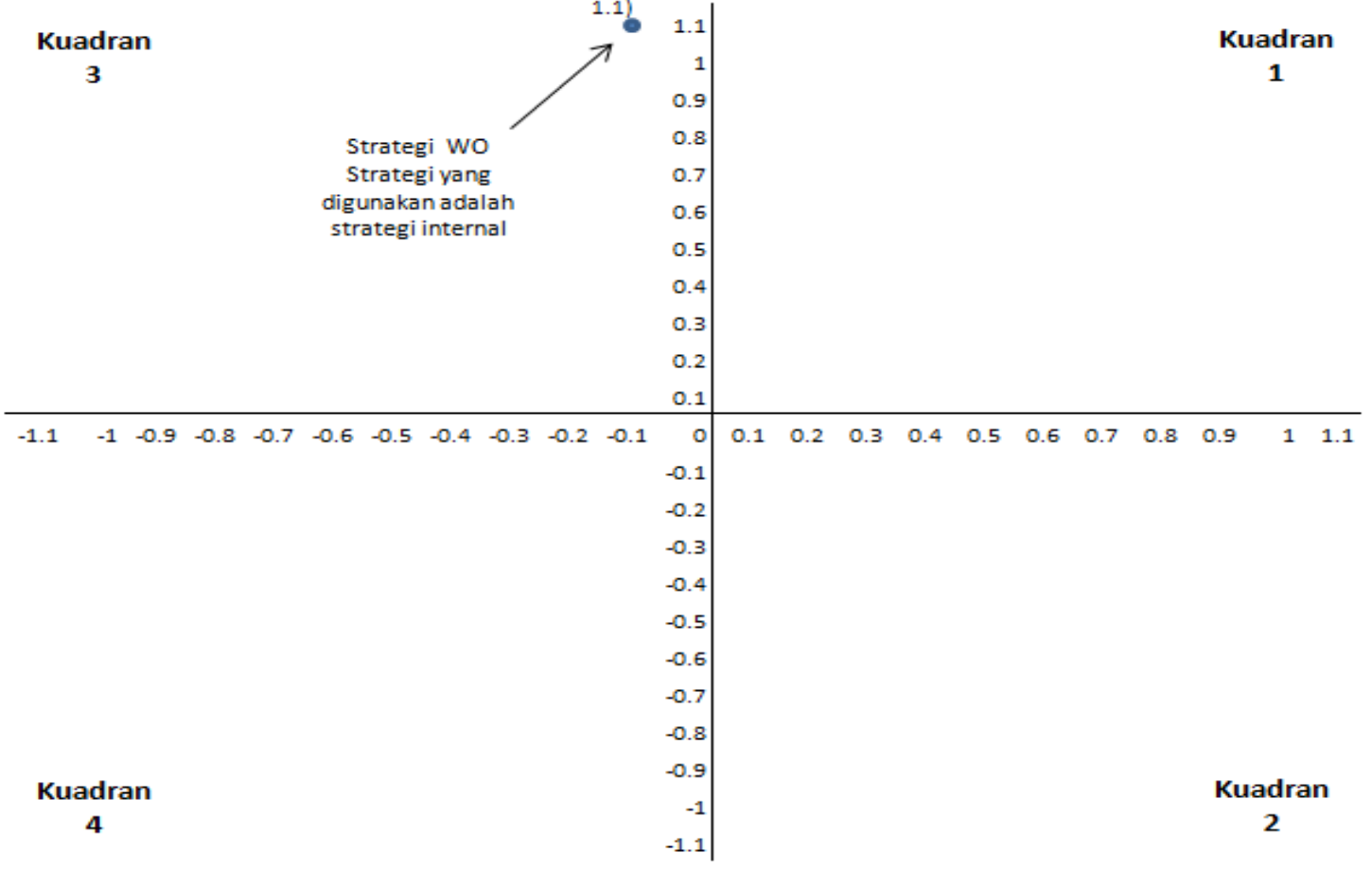

Gambar 3. Diagram SWOT Pengembangan E-Tourism di Pulau Lombok

Perhitungan skor dilakukan dengan melihat tingkat pengaruh antara variabel yang satu dengan variabel yang lainnya pada masing-masing strategi. Untuk pembobotan dilakukan dengan memberikan nilai antara 1 sampai dengan 4 berdasarkan besar kecil kepentingan variabel tersebut. Total nilai diperoleh dengan mengalikakan skor dengan bobot dan dijumlahkan masingmasing strategi. Untuk menentukan kondisi dan strategi digunakan diagram kartesius seperti pada Gambar 3. Nilai sumbu titik $x$ diperoleh dengan mengurangi total faktor pada faktor kekuatan dan factor Kelemahan.

$\mathrm{SW}=$ total factor kekuatan - total factor kelemahan

$=2.94-3.06$

$=-0.12($ sumbu titik $\mathrm{x})$

Sedangkan sumbu titik y diperoleh dengan mengurangi total faktor peluang dengan ancaman.

OT = total faktor peluang - total faktor ancaman

$=3.29-2.19$

$=2.19$ (sumbu titik y)

Kemudian sumbu titik (x,y) dimasukkan pada diagram kartesius seperti pada Gambar 3. Berdasarkan analisis SWOT diketahui bahwa kondisi pengembangan e-tourism di Pulau Lombok berada pada kuadran III sehingga strategi yang digunakan adalah strategi WO (WeaknessOpportunity) yaitu strategi yang melihat peluang yang ada sekaligus menghadapi ancaman (strategi turn-arround). Strategi WO yang digunakan adalah melakukan kordinasi secara internal untuk mendapatkan peluang yang ada dan mengubah strategi sebelumnya untuk mengatasi ancaman. Adapun beberapa rencana strategi WO yang dapat digunakan untuk pengembangan e-tourism di Pulau Lombok sebagai berikut:

1. Meningkatkan jumlah website pariwisata (e-tourism) yang ada serta melakukan pembaharuan informasi serta konten pada website tersebut. Pada website pariwisata 
yang dibangun juga perlu ditambahkan beberapa fitur seperti informasi tempat umum, serta chat room dan Frequently Asked Questions (FAQ) untuk memfasilitasi pengguna jika ingin bertanya atau berkonsultasi terkait objek wisata di Pulau Lombok. Untuk itu Dinas Kebudayaan dan Pariwisata perlu mempersiapkan sumber daya manusia yang mahir di bidang jaringan dan internet.

2. Melakukan optimalisasi dengan Search Engine Optimization (SEO) pada website pariwisata Lombok untuk menaikkan rangking traffic pencarian pariwisata Lombok sehingga pengguna dapat dengan mudah mencari informasi pariwisata melalui internet. Promosi dengan optimasi mesin pencarian (search engine) seperti Google, Bing, dan Yahoo dilakukan agar wisatawan dapat merujuk pada pariwisata Pulau Lombok. Untuk optimalisasi dapat menggunakan kata kunci seperti pantai, petualangan alam (termasuk surfing, diving, trekking, dII), budaya, kuliner, interaksi dengan masyarakat setempat, dan gelaran budaya.

3. Perlu adanya sistem pariwisata yang terintegrasi untuk memudahkan dalam transaksi data antara website yang satu dengan website lainnya. Integrasi data dilakukan pada website pariwisata (e-tourism) dengan website atau sistem perhotelan, agen perjalanan, maskapai penerbangan, rumah makan, dan lainnya yang terkait dengan pariwisata. Untuk hal ini Dinas Kebudayaan dan Pariwisata Provinsi Nusa Tenggara Barat perlu membangun sebuah basis data kepariwisataan Lombok yang terintegrasi.

4. Dinas Kebudayaan dan Pariwisata Provinsi Nusa Tenggara Barat, Badan Promosi Pariwisata Daerah (BPPD) Provinsi Nusa Tenggara Barat atau instansi terkait dapat bekerja sama dengan agen perjalan agar agen perjalanan wisata tidak hanya menjual produk/jasa, tetapi juga membantu dalam mempromosikan pariwisata melalui internet serta menaikkan rangking traffic pariwisata Lombok.

5. Mendorong berkembangnya startup di bidang pariwisata seperti ITX dan Lombok Travel Mart yang tidak hanya membantu mempromosikan pariwisata, tetapi juga membantu wisatawan dalam melakukan transaksi pembayaran seperti pembayaran agen perjalanan, hotel, transportasi, dan lain-lain. Hal ini dapat memberikan kemudahan kepada wisatawan dalam melakukan transaksi secara online.

6. Meningkatkan promosi pariwisata (e-tourism) di bidang kebudayaan dalam bentuk sinema digital yang bertema budaya. Hal ini dipandang perlu sebagai salah satu strategi promosi pariwisata melalui internet mengingat saat ini promosi pariwisata di Pulau Lombok masih mengangkat keindahan alam objek wisata.

7. Mengelola jejaring sosial seperti Facebook, Twitter, Instragram, Youtube, dan yang lainnya untuk promosi pariwisata. Selain itu juga dapat menggunakan teknik promosi mouth to mouth yaitu melakukan perbincangan serta review pariwisata Pulau Lombok di internet.

8. Melakukan promosi wisata halal sebagai branding pariwisata di Pulau Lombok. Hal ini sesuai dengan Pergub Nomor 51 tahun 2015 tentang Wisata Halal dan Peraturan Daerah Nomor 2 Tahun 2016 tentang Pariwisata Halal.

\section{Kesimpulan dan Saran}

Guna mendukung program kerja, kebijakan, dan strategi pemerintah dalam meningkatkan kunjungan wisatawan di Pulau Lombok, Pemerintah Provinsi Nusa Tenggara Barat telah melakukan beberapa upaya promosi melalui pemanfaatan media seperti media cetak, media TV, internet, radio, mengikuti event pariwisata dan sebagainya. Media promosi yang digunakan dalam mendukung promosi pariwisata Pulau Lombok salah satunya melalui internet dengan etourism. Dari penelitian yang telah dilakukan dengan analisis SWOT terkait dengan evaluasi pengembangan e-tourism di Pulau Lombok diketahui bahwa strategi yang harus digunakan pemerintah adalah strategi WO yaitu berfokus untuk melakukan koordinasi secara internal, melakukan evaluasi diri terhadap penerapan e-tourism serta evaluasi yang sistematis terhadap penerapan promosi melalui internet dan meningkatkan strategi promosi pariwisata melalui internet.

Penelitian ini hanya berfokus pada melihat kondisi penerapan e-tourism di Pulau Lombok dalam hal faktor internal dan faktor eksternal yang dapat dijadikan bahan evaluasi bagi Dinas Kebudayaan dan Pariwisata Provinsi Nusa Tenggara Barat serta instansi terkait strategi dan arahan kebijakan dalam penerapan e-tourism. Penelitian selanjutnya dapat membuat sistem aplikasi yang dapat memberikan rekomendasi objek wisata kepada wisatawan berdasarkan karakteristik wisatawan. 


\section{Daftar Pustaka}

[1] Anonim. 2017. The most beautiful country in the world-as voted by you. [online].(https://www.roughguides.com/gallery/most-beautiful-country-in-the-world/ ). Diakses tanggal 05 Oktober 2017).

[2] Ros. 2017. Lombok kembali raih tiga juara dalam ajang "World Halal Tourism Awards 2016". [online].(http://www.suarantb.com/news/2016/12/08/16667/lombok.kembali.raih.tiga.juara.dala m.ajang.world.halal.tourism.awards.2016 ). diakses pada tanggal 06 Oktober 2017.

[3] BPS. 2016. Provinsi Nusa Tenggara Barat dalam Angka 2016. Mataram. CV.Maharani.

[4] anonim. 2016. Pariwisata NTB sabet tiga penghargaan internasional. [online]. (https://radarlombok.co.id/pariwisata-ntb-sabet-tiga-penghargaan-internasional.html). Diakses pada tanggal 06 Oktober 2017.

[5] Ismayanti. (2010). Pengantar Pariwisata, Jakarta :Grasindo.

[6] UNCTAD. 2004. UNCTAD's e-tourism initiative. [online]. (www.unctad.org/en/Docs/tdxipbd6_en.pdf). Diakses pada 05 Oktober 2017.

[7] Santosa, Budi, Hessel. 2002. Strategi Pengembangan Sektor Pariwisata. Yogyakarta: YPAPI

[8] Rangkuti, F. 2006.Analisis SWOT Teknik Membedah Kasus Bisnis. Cetakan Keduabelas. PT Gramedia Pustaka Utama. Jakarta.

[9] Robinson, Pearce. (2001). Strategic Management : Formulation, Implementation and Control. Seventh edition. McGraw. Hill Book International. 